\title{
An Examination of Phubbing and Being Phubbed Behaviors Among Turkish Teachers
}

\section{Emre Suzer ${ }^{1}$ iD and Mustafa Koc $^{2}$ (i)}

\begin{abstract}
In this study, it was aimed to examine teachers' level of phubbing and being phubbed in terms of various variables. The study was designed as a survey research with a target population of teachers working in the Turkish public schools during the 2020-2021 academic years. The sample was formed using a convenience sampling method and made up of 307 (141 female, 166 male) teachers whose ages ranged from 23 to 64. Research data were collected through a questionnaire including "Personal Information Form", "Generic Scale of Phubbing (GSP)" and "Generic Scale of Being Phubbed (GSBP)". Descriptive statistics, correlation analyses and multivariate analysis of variance (MANOVA) tests were conducted for the analysis of the collected data. As a result of the research, participating teachers' level of phubbing and being phubbed were determined as moderate level. There was no significant difference in terms of gender, educational status and branch variables. Regarding marital status variable, nomophobia and self-isolation levels of single teachers were found to be higher than those of married ones. Age was found to be negatively and weakly correlated with the levels of self-isolation. In addition, the levels of phubbing were found to be positively and moderately associated with the levels of being phubbed.
\end{abstract}

Keywords: Phubbing, being phubbed, nomophobia, self-isolation, teacher

With the development of mobile technologies, the usage of smartphones has greatly increased. According to the "We Are Social Turkey" report published in January 2021, 97.2\% of individuals aged 16-64 use smartphones, $94.2 \%$ of internet users connect to the internet via smartphones, and smartphone users mostly spend their time on social media such as YouTube, Instagram and WhatsApp (Kemp, 2021). Smartphones are devices that offer advanced technologies, work like a computer, support multitasking and make it easier to stay connected with others (Anshari et al., 2016). Smartphones have become important communication tools with these features that make daily life much easier. However, it is thought that smartphones might harm face-to-face communication between individuals and cause various problems (Chotpitayasunondh \& Douglas, 2016; Erzen et al., 2021; Turkle, 2011). The concept of phubbing is one of these problems.

Phubbing refers to a condition in which a person pays attention to the smartphone during communication with another person, deals with the smartphone and thus loses his/her perception from interpersonal communication (Chotpitayasunondh \& Douglas, 2016; Karadağ et al., 2016). The concept of phubbing was derived by the team in charge of updating the MacGuarie Dictionary, combining the words phone (phone) and snubbing (Karadağ et al., 2015). It is stated that phubbing, which is accepted as a multidimensional structure, can be explained by smartphone addiction, social media addiction, internet addiction, game and application addiction (Karadağ et al., 2016). In addition, it was concluded that phubbing was moderately associated with smartphone addiction, internet addiction and fear of kidnapping (FOMO) (Chotpitayasunondh \& Douglas, 2016). However, phubbing also occurs when people belittle or ignore other people around them by focusing on their smartphones (Nazir \& Pişkin, 2016; Ugur $\&$ Koc, 2015). Phubbing is seen with the components of a phubber (a person who is phubbing), phubbe(s) (persons who are being phubbed) and social environment, but if a person uses a smartphone without another individual in

${ }^{1}$ Graduate School of Educational Sciences, Suleyman Demirel University, Isparta, Turkey

${ }^{2}$ Department of Educational Sciences, Suleyman Demirel University, Isparta, Turkey

Corresponding Author: Mustafa Koc, Department of Educational Sciences, Faculty of Education, Suleyman Demirel University, Isparta, Turkey.

Email: mustafakoc@sdu.edu.tr 
the environment, phubbing is not seen (Nazir, 2020). Individuals being phubbed state that their social needs are prevented from being met and they cannot communicate with the other persons (Chotpitayasunondh \& Douglas, 2018b; Krasnova et al., 2016). Phubbing can damage relationships in various social environments (Karadağ et al., 2016; Roberts \& David, 2016, 2017; Ugur \& Koc, 2015).

\section{Literature Review}

When the related literature was examined, it was seen that various studies were conducted on phubbing. For example, Karadağ et al. (2015) examined the dimensions of phubbing behavior in a study with 409 university students. They concluded that mobile phone, SMS, social media and internet addiction were important determinants. Chotpitayasunondh and Douglas (2016), in their study with 276 participants between the ages of 18 and 66, concluded that phubbing was moderately associated with smartphone addiction, internet addiction, and fear of missing out (FOMO). Nazir and Pişkin (2016), in their study examining the effects of phubbing and smartphone use on individuals, stated that frequently looking at the phone during a social conversation caused the person on the other side to think that they did not care about themselves.

Karadağ et al. (2016) analyzed the potential causes and effects of phubbing through semi-structured interviews with nine young adults studying at the faculty of education. They revealed that phubbers had inadequacy in terms of communication skills, had difficulty in making eye contact with others, misunderstood what was being said, and some completely closed themselves to what was going on around them.

Chotpitayasunondh and Douglas (2018a) developed the Generic Phubbing Scale (GSP) and the Generic Scale Being Phubbed (GSBP) in their study. These scales were adapted into Turkish by Orhan Göksun (2019). In the study conducted by Yam and Kumcagiz (2020) with the participation of university students in order to adapt the GSP to Turkish culture, the variables of phone addiction, fear of missing out and susceptibility to boredom were found to be significant predictors of phubbing. Ergün et al. (2020) aimed to adapt the GSP and GSBP to Turkish language and culture and to investigate the relationships between various variables. They found that phubbing was positively associated with anxiety, depression, negative self, somatization, hostility, life satisfaction except for loneliness and it was strongly related to the duration of phone use. They also showed that anxiety, negative self and hostility were significant predictors for phubbing.

In his study to understand the effect and emotional reactions of student phubbing on university instructors during the lesson, Nazir (2020) stated that young university instructors considered students' phubbing behaviors as a condition reducing their course performance whereas older instructors considered them as disrespectfulness. Aydoğdu and Çevik (2020) examined 115 school counselors' levels of phubbing, being phubbed and loneliness. As a result, they determined that there was a significant relationship between phubbing and loneliness, and between phubbing and being phubbed. In addition, they suggested that phubbing should be investigated amongst the teachers. On the other hand, 46 in-service and 247 pre-service teachers participated in the study in which İliç and Tanyeri (2021) aimed to examine the status of phubbing and being phubbed according to age and gender. It was seen that there was no difference in terms of gender and age, but the phubbing behavior tended to increase as they got older.

In the teaching profession, where communication skills are very effective, it is important to know the status of phubbing that harms face-to-face communication. When prior studies in the literature were examined, it was found that studies examining the phubbing levels of different populations. However, no study has been found that directly examines teachers' phubbing levels and evaluates it in terms of various variables. Based on this rationale, it is thought that conducting such a study on teachers will contribute to the literature. Therefore, the aim of this study is to determine teachers' level of phubbing and being phubbed in terms of various variables such as age, gender, branch, period of service, and duration of smartphone ownership. In order to fulfill this purpose, the following research questions were formulated:

1. What are the teachers' levels of phubbing and being phubbed?

2. Do teachers' levels of phubbing and being phubbed differ significantly in terms of gender, marital status, educational status, and branch?

3. Are teachers' levels of phubbing and being phubbed significantly associated with age, work experience and smartphone use? 


\section{Method}

\section{Research Design}

The study was designed as a survey research within the quantitative research paradigm. The survey design is a popular approach in educational research context with its many applications. It is a non-experimental design that enables researchers to describe a sample or population's attitudes, ideas, behaviors, or characteristics (Creswell, 2012; Şen \& Y1ldırım, 2019). In this study, since the teachers' level of phubbing and being phubbed were examined in terms of various variables, the survey design was thought to be appropriate method.

\section{Participants}

The target population of this research consists of teachers working in the Turkish public schools of Ministry of National Education of during the 2020-2021 academic years. The convenience sampling, one of the nonprobabilistic sampling methods, was employed to recruit the research participants. Convenience sampling, also called as easily accessible case sampling or accidental sampling, is the method in which units that are easy to reach are selected as samples (Şen \& Yıldırım, 2019).

Table I. Demographic characteristics of the participants

\begin{tabular}{lcc}
\hline Characteristic & Frequency & Percentage \\
\hline Gender & & 46 \\
Women & 141 & 54 \\
Male & 166 & 75 \\
Marital Status & & 25 \\
Married & 230 & \\
Single & 77 & 81 \\
Education Level & & 19 \\
Undergraduate & 250 & \\
Graduate & 57 & 29 \\
Branch & & 33 \\
Math and Science Fields & 90 & 18 \\
Social Fields & 101 & 20 \\
Talent \& Artistic Fields & 55 & 100 \\
Primary Education Fields & 61 & \\
Total & 307 & \\
\hline
\end{tabular}

The sample was made up of 307 (141 female, 166 male) teachers. Their age ranged from 23 to 64 with an average age of 36.22 years $(S D=7.56)$. Their work experience varied between 1 and 40 year with an average experience of 12.34 years $(S D=7.67)$. The frequency analysis of the other demographic characteristics of the participants is given in Table 1. Regarding participants' branches, mathematics, biology, science, physics, chemistry and information technologies were categorized as "math and science fields"; geography, religious culture and ethics, philosophy, history, literature, social studies, Turkish and foreign language teaching branches were categorized as "social fields"; physical education, music, visual arts, technology design and vocational teaching were categorized as "talent and artistic fields"; classroom teaching, guidance, special education and pre-school teaching were categorized as "primary education fields".

\section{Measures}

Research data were collected through a questionnaire including "Personal Information Form", "Generic Scale of Phubbing (GSP)" and "Generic Scale of Being Phubbed (GSBP)". Personal information form includes questions to learn about variables such as teachers' gender, age, marital status, branch, work experience, and duration of smartphone ownership.

The GSP and GSBP was developed by Chotpitayasunondh and Douglas (2018a) and adapted into Turkish language and culture by Orhan Göksün (2019). Both scales are rated on a seven-point Likert type scale (1=Never, 2=Rarely, $3=$ Occasionally, 4=Sometimes, 5=Often, 6=Usually, 7=Always). The GSP consists of a total of 15 items under four factors: "nomophobia", "interpersonal conflict", "self-isolation" and "problem acknowledgement". Definitions of these factors can be made as follows (Chotpitayasunondh \& Douglas, 2018a). Nomophobia is expressed as the fear 
of leaving the smartphone. Interpersonal conflict is defined as the perceived conflict between oneself and others due to smartphone use. Self-Isolation is expressed as the tendency to use the smartphone to escape from social activities and isolate oneself from others. Problem acknowledgment is about individuals' acceptance of being a phubber as a problem. On the other hand, the GSBP consists of a total of 22 items under three factors: "perceived norms", "feeling ignored" and "interpersonal conflict". Perceived norms include perceptions of what others are doing with their smartphones. Feeling ignored is related to the feeling of being ignored by others due to smartphone use. Orhan Göksün (2019) found Cronbach alpha internal consistency coefficients for the factors of the GSP and GSBP as ranging from .73 to .84 and .83 to .92 respectively. In this study, the coefficients for the factors ranged from .74 to .91 for the GSP and .89 to .96 for the GSBP.

Table 2. Descriptive statistics of the GSP and GSBP factors

\begin{tabular}{lcc}
\hline Factor & Mean & $S D$ \\
\hline$G S P$ & & \\
Nomophobia & 4.43 & 1.30 \\
Interpersonal Conflict & 2.11 & 1.15 \\
Self-Isolation & 2.30 & 1.24 \\
Problem Acknowledgment & 2.87 & 1.37 \\
Overall Average & 2.93 & 1.00 \\
$G S B P$ & & \\
Perceived Norms & 4.64 & 1.17 \\
Feeling Ignored & 2.86 & 1.36 \\
Interpersonal Conflict & 2.63 & 1.31 \\
Overall Average & 3.59 & 1.00 \\
\hline
\end{tabular}

\section{Data Analyses}

SPSS statistical package program was used to analyze the collected data. Whether the data showed univariate normality or not was checked with skewness and kurtosis coefficients, Q-Q normality plots and histograms. As a result of this preliminary examination, it was seen that all the variables displayed a normal distribution (Tabachnick \& Fidell, 2013). Descriptive statistics, correlation coefficients and multivariate analysis of variance (MANOVA) tests were conducted in the analysis of the data. The assumptions of MANOVA were diagnosed and found to be met. These are multivariate normality checked with the examination of Mahalanobis distance values, linearity and multicolinearity checked with scatter plots and Pearson correlation coefficients, and homogeneity of variancecovariance matrices checked with Box's M test (Büyüköztürk, 2020; Tabachnick \& Fidell, 2013). The significance level was determined as $.05 / 7=.007$ ( .01) by using Bonferroni correction in order not to be affected by a possible Type-1 error.

Table 3. MANOVA results for level of phubbing and being phubbed by gender

\begin{tabular}{|c|c|c|c|c|c|c|}
\hline Factor & Gender & $N$ & Mean & $S D$ & $F$ & $\eta^{2}$ \\
\hline \multirow{2}{*}{ Nomophobia } & Male & 166 & 4.39 & 1.31 & \multirow{2}{*}{.35} & \multirow{2}{*}{.00} \\
\hline & Female & 144 & 4.48 & 1.29 & & \\
\hline \multirow{2}{*}{ Interpersonal Conflict (GSP) } & Male & 166 & 2.17 & 1.17 & \multirow{2}{*}{1.20} & \multirow{2}{*}{.00} \\
\hline & Female & 144 & 2.03 & 1.12 & & \\
\hline \multirow{2}{*}{ Self-Isolation } & Male & 166 & 2.26 & 1.26 & \multirow{2}{*}{.40} & \multirow{2}{*}{.00} \\
\hline & Female & 144 & 2.35 & 1.22 & & \\
\hline \multirow{2}{*}{ Problem Acknowledgment } & Male & 166 & 2.95 & 1.38 & \multirow{2}{*}{1.39} & \multirow{2}{*}{.00} \\
\hline & Female & 144 & 2.77 & 1.37 & & \\
\hline \multirow{2}{*}{ Perceived Norms } & Male & 166 & 4.68 & 1.06 & \multirow{2}{*}{.42} & \multirow{2}{*}{.00} \\
\hline & Female & 144 & 4.59 & 1.29 & & \\
\hline \multirow{2}{*}{ Feeling Ignored } & Male & 166 & 2.82 & 1.26 & \multirow{2}{*}{.18} & \multirow{2}{*}{.00} \\
\hline & Female & 144 & 2.89 & 1.46 & & \\
\hline \multirow[t]{2}{*}{ Interpersonal Conflict (GSBP) } & Male & 166 & 2.48 & 1.04 & \multirow{2}{*}{4.45} & \multirow[b]{2}{*}{.01} \\
\hline & Female & 144 & 2.80 & 1.56 & & \\
\hline
\end{tabular}

Note: Pillai's Trace $=.04, F_{(7,299)}=2.38, p<.05$. 


\section{Results}

The descriptive statistics for participants' scores from both the GSP and GSBP are given in Table 2. As far as GSP scores are concerned, teachers showed moderate levels of nomophobia (Mean=4.43, $\mathrm{SD}=1.30$ ) and problem acknowledgement (Mean=2.87, SD=1.37) and low levels of interpersonal conflict (Mean=2.11, SD=1.15) and selfisolation (Mean=2.30, $\mathrm{SD}=1.24$ ). Their overall level of phubbing was moderate (Mean=2.93, $\mathrm{SD}=1.00$ ). Regarding GSBP scores, teachers reported moderate level of perceived norms (Mean=4.64, SD=1.17), feeling ignored (Mean=2.86, $\mathrm{SD}=1.36$ ) and interpersonal conflict (Mean=2.63, $\mathrm{SD}=1.31$ ). Their overall level of being phubbed was moderate $($ Mean $=3.59, \mathrm{SD}=1.00)$.

Table 4. MANOVA results for level of phubbing and being phubbed by marital status

\begin{tabular}{|c|c|c|c|c|c|c|}
\hline Factor & Marital & $N$ & Mean & $S D$ & $F$ & $\overline{\eta^{2}}$ \\
\hline \multirow[t]{2}{*}{ Nomophobia } & Married & 230 & 4.30 & 1.28 & \multirow{2}{*}{$10.23 *$} & \multirow{2}{*}{.03} \\
\hline & Single & 77 & 4.83 & 1.28 & & \\
\hline \multirow[t]{2}{*}{ Interpersonal Conflict (GSP) } & Married & 230 & 2.11 & 1.12 & \multirow{2}{*}{.00} & \multirow{2}{*}{.00} \\
\hline & Single & 77 & 2.10 & 1.23 & & \\
\hline \multirow[t]{2}{*}{ Self-Isolation } & Married & 230 & 2.18 & 1.17 & \multirow{2}{*}{$9.35^{*}$} & \multirow{2}{*}{.03} \\
\hline & Single & 77 & 2.67 & 1.39 & & \\
\hline \multirow[t]{2}{*}{ Problem Acknowledgment } & Married & 230 & 2.80 & 1.33 & \multirow{2}{*}{2.11} & \multirow{2}{*}{.01} \\
\hline & Single & 77 & 3.06 & 1.50 & & \\
\hline \multirow[t]{2}{*}{ Perceived Norms } & Married & 230 & 4.58 & 1.21 & \multirow{2}{*}{2.70} & \multirow{2}{*}{.01} \\
\hline & Single & 77 & 4.83 & 1.04 & & \\
\hline \multirow[t]{2}{*}{ Feeling Ignored } & Married & 230 & 2.88 & 1.34 & \multirow{2}{*}{.38} & \multirow{2}{*}{.00} \\
\hline & Single & 77 & 2.77 & 1.41 & & \\
\hline \multirow[t]{2}{*}{ Interpersonal Conflict (GSBP) } & Married & 230 & 2.74 & 1.34 & \multirow{2}{*}{6.42} & \multirow{2}{*}{.02} \\
\hline & Single & 77 & 2.30 & 1.18 & & \\
\hline
\end{tabular}

Note: Wilk's Lambda $=.10, F_{(7,209)}=5.30, p<.01 . * p<.01$

A MANOVA test was conducted to determine whether there was a significant difference according to gender on the teachers' GSP and GSBP factor scores (Table 3). The preliminary examination of factor scores indicated that they were significantly and moderately correlated with each other (Table 7) and the multicolinearity assumption was met. The homogeneity assumption of the spread matrix was not provided according to the Box M statistic and thus the Pillai's Trace value was employed. Considering the one-way ANOVA results for each factor, no significant difference was found in any of the factor scores across the gender.

Table 5. MANOVA results for level of phubbing and being phubbed by education level

\begin{tabular}{|c|c|c|c|c|c|c|}
\hline Factor & Education & $N$ & Mean & $S D$ & $F$ & $\eta^{2}$ \\
\hline \multirow{2}{*}{ Nomophobia } & Undergraduate & 250 & 4.38 & 1.32 & \multirow{2}{*}{2.50} & \multirow{2}{*}{.00} \\
\hline & Graduate & 57 & 4.68 & 1.17 & & \\
\hline \multirow{2}{*}{ Interpersonal Conflict (GSP) } & Undergraduate & 250 & 2.09 & 1.17 & \multirow{2}{*}{.51} & \multirow{2}{*}{.00} \\
\hline & Graduate & 57 & 2.21 & 1.06 & & \\
\hline \multirow{2}{*}{ Self-Isolation } & Undergraduate & 250 & 2.29 & 1.28 & \multirow{2}{*}{.26} & \multirow{2}{*}{.00} \\
\hline & Graduate & 57 & 2.38 & 1.07 & & \\
\hline \multirow{2}{*}{ Problem Acknowledgment } & Undergraduate & 250 & 2.83 & 1.41 & \multirow{2}{*}{1.10} & \multirow{2}{*}{.00} \\
\hline & Graduate & 57 & 3.04 & 1.19 & & \\
\hline \multirow{2}{*}{ Perceived Norms } & Undergraduate & 250 & 4.67 & 1.15 & \multirow{2}{*}{.97} & \multirow{2}{*}{.00} \\
\hline & Graduate & 57 & 4.50 & 1.26 & & \\
\hline \multirow{2}{*}{ Feeling Ignored } & Undergraduate & 250 & 2.87 & 1.37 & \multirow{2}{*}{.07} & \multirow{2}{*}{.00} \\
\hline & Graduate & 57 & 2.81 & 1.29 & & \\
\hline \multirow[t]{2}{*}{ Interpersonal Conflict (GSBP) } & Undergraduate & 250 & 2.65 & 1.36 & \multirow{2}{*}{.35} & \multirow{2}{*}{.00} \\
\hline & Graduate & 57 & 2.54 & 1.10 & & \\
\hline
\end{tabular}

Note: Pillai's Trace $=.04, F_{(7,299)}=.19, p>0.05$. 
Another MANOVA test was conducted to determine whether there was a significant difference according to the marital status variable on the teachers' GSP and GSBP factor scores (Table 4). The preliminary examination of factor scores indicated that they were significantly and moderately correlated with each other (Table 7) and the multicolinearity assumption was met. The homogeneity assumption of the spread matrix was provided according to the Box M statistic and thus Wilk's Lambda value was employed. When the one-way ANOVA results for all the factors were examined, significant differences were found in nomophobia $\left[\mathrm{F}_{(1,305)}=10.23, \eta^{2}=.03, \mathrm{p}<.01\right]$ and selfisolation $\left[\mathrm{F}_{(1,305)}=9.35, \eta^{2}=.03, \mathrm{p}<.01\right]$ factors. Single/Widowed teachers have higher nomophobia and self-isolation scores than married teachers. However, the effect of marital status on these dimensions is quite low and explains only $3 \%$ of the total variance.

Table 6. MANOVA results for level of phubbing and being phubbed by branch

\begin{tabular}{|c|c|c|c|c|c|c|}
\hline Factor & Branch & $\mathrm{N}$ & Mean & $\mathrm{SD}$ & $\mathrm{F}$ & $\eta 2$ \\
\hline \multirow{4}{*}{ Nomophobia } & Math and Science Fields & 90 & 4.64 & 1.21 & \multirow{4}{*}{3.09} & \multirow{4}{*}{.00} \\
\hline & Social Fields & 101 & 4.48 & 1.26 & & \\
\hline & Talent \& Artistic Fields & 55 & 3.98 & 1.40 & & \\
\hline & Primary Education Fields & 61 & 4.45 & 1.33 & & \\
\hline \multirow{4}{*}{ Interpersonal Conflict (GSP) } & Math and Science Fields & 90 & 2.12 & 1.17 & \multirow{4}{*}{.26} & \multirow{4}{*}{.00} \\
\hline & Social Fields & 101 & 2.17 & 1.17 & & \\
\hline & Talent \& Artistic Fields & 55 & 2.00 & 1.00 & & \\
\hline & Primary Education Fields & 61 & 2.09 & 1.25 & & \\
\hline \multirow{4}{*}{ Self-Isolation } & Math and Science Fields & 90 & 2.40 & 1.29 & \multirow{4}{*}{.67} & \multirow{4}{*}{.00} \\
\hline & Social Fields & 101 & 2.30 & 1.21 & & \\
\hline & Talent \& Artistic Fields & 55 & 2.10 & 1.07 & & \\
\hline & Primary Education Fields & 61 & 2.34 & 1.37 & & \\
\hline \multirow{4}{*}{ Problem Acknowledgment } & Math and Science Fields & 90 & 2.95 & 1.42 & \multirow{4}{*}{1.34} & \multirow{4}{*}{.00} \\
\hline & Social Fields & 101 & 2.90 & 1.37 & & \\
\hline & Talent \& Artistic Fields & 55 & 2.54 & 1.29 & & \\
\hline & Primary Education Fields & 61 & 2.99 & 1.39 & & \\
\hline \multirow{4}{*}{ Perceived Norms } & Math and Science Fields & 90 & 4.65 & 1.26 & \multirow{4}{*}{.13} & \multirow{4}{*}{.00} \\
\hline & Social Fields & 101 & 4.69 & 1.17 & & \\
\hline & Talent \& Artistic Fields & 55 & 4.63 & .98 & & \\
\hline & Primary Education Fields & 61 & 4.57 & 1.20 & & \\
\hline \multirow{4}{*}{ Feeling Ignored } & Math and Science Fields & 90 & 2.80 & 1.43 & \multirow{4}{*}{.70} & \multirow{4}{*}{.00} \\
\hline & Social Fields & 101 & 3.01 & 1.35 & & \\
\hline & Talent \& Artistic Fields & 55 & 2.73 & 1.22 & & \\
\hline & Primary Education Fields & 61 & 2.79 & 1.39 & & \\
\hline \multirow{4}{*}{ Interpersonal Conflict (GSBP) } & Math and Science Fields & 90 & 2.52 & 1.32 & \multirow{4}{*}{.39} & \multirow{4}{*}{.00} \\
\hline & Social Fields & 101 & 2.64 & 1.24 & & \\
\hline & Talent \& Artistic Fields & 55 & 2.76 & 1.24 & & \\
\hline & Primary Education Fields & 61 & 2.65 & 1.49 & & \\
\hline
\end{tabular}

Note: Wilk's Lambda $=.07, F_{(21,853)}=.96, p>.05$.

One another MANOVA test was conducted to determine whether there was a significant difference according to the education level variable on the teachers' GSP and GSBP factor scores (Table 5). The preliminary examination of factor scores indicated that they were significantly and moderately correlated with each other (Table 7) and the multicolinearity assumption was met. The homogeneity assumption of the spread matrix was not provided according to the Box M statistic and thus the Pillai's Trace value was employed. Considering the one-way ANOVA results for each variable, no significant difference was found in any of the factor scores with regards to the education level variable. 
Table 7. Correlation coefficients for the study variables

\begin{tabular}{lcccccccccc}
\hline Variable & 1 & 2 & 3 & 4 & 5 & 6 & 7 & 8 & 9 & 10 \\
\hline 1. Age & - & $.94^{* *}$ & $.11^{*}$ & -.09 & -.01 & $-.12^{*}$ & -.01 & .01 & -.01 & .01 \\
2. Work experience & & - & $.11^{*}$ & -.08 & .02 & -.08 & -.06 & -.03 & -.01 & .01 \\
3. Duration of smartphone use & & & - & .05 & .04 & .09 & .03 & -.05 & .01 & -.05 \\
4. Nomophobia & & & & - & $.46^{* *}$ & $.38^{* *}$ & $.44^{* *}$ & $.31^{* *}$ & $.22^{* *}$ & .06 \\
5. Interpersonal Conflict (GSP) & & & & & - & $.63^{* *}$ & $.64^{* *}$ & $.17^{* *}$ & $.33^{* *}$ & $.22^{* *}$ \\
6. Self-Isolation & & & & & & - & $.55^{* *}$ & $.27^{* *}$ & $.42^{* *}$ & $.19^{* *}$ \\
7. Problem Acknowledgment & & & & & & & - & $.32^{* *}$ & $.38^{* *}$ & $.21^{* *}$ \\
8. Perceived Norms & & & & & & & & - & $.40^{* *}$ & $.30^{* *}$ \\
9. Feeling Ignored & & & & & & & & & - & $.58^{* *}$ \\
10. Interpersonal Conflict (GSBP) & & & & & & & & & & \\
\hline
\end{tabular}

$* \mathrm{p}<, 05 . * * \mathrm{p}<, 01$.

A final MANOVA test was conducted to determine whether there was a significant difference according to branch variable on the teachers' GSP and GSBP factor scores (Table 6). The preliminary examination of factor scores indicated that they were significantly and moderately correlated with each other (Table 7) and the multicolinearity assumption was met. The homogeneity assumption of the spread matrix was provided according to the Box $\mathrm{M}$ statistic and thus the Wilk's Lambda value was employed. The findings showed that teachers' factor scores did not differ significantly according to their branches.

Table 7 shows the findings for the relationships between teachers' level of phubbing and being phubbed and demographic variables such as age, work experience, and smartphone usage. When the Pearson correlation coefficients related to GSP and GSBP are examined, it is seen that only the age variable is negatively and weakly related to the self-isolation scores ( $\mathrm{r}=-.12, \mathrm{p}<.05)$. In addition, the majority of the factor scores of GSP and GSBP are significantly and positively related to each other.

\section{Discussion}

This study aimed to examine teachers' level of phubbing and being phubbed in terms of various variables. As a result of the research, it was determined that teachers' levels phubbing and being phubbed were in the medium range. When the factor scores of the GSP are examined, it can be said that the nomophobia scores, which is called the fear of leaving the smartphone, are relatively high compared to the other dimensions although they are in the middle range. Considering that the interpersonal conflict and self-isolation factors of GSP are in the low range, it can be thought that the reasons for teachers' phubbing behaviors are the concerns of being away from the smartphone rather than social issues. Obtaining a similar result, Yam and Kumcagiz (2020) stated that the phubbing levels of university students increased because of nomophobia.

As far the levels of teachers' phubbing and being phubbed across the demographic characteristics are concerned, there are no gender differences. This result coincides with the result of the study on school psychological counselors conducted by Aydoğdu and Çevik (2020). It also corroborates with the result of study on teachers and teacher candidates conducted by İliç and Tanyeri (2021). However, it is not consistent with studies on university graduates (Roberts et al., 2014) and university graduates (Karadağ et al., 2015). When the results are compared, it can be said that the phubbing levels of individuals in the society may differ with the gender variable, but there is no such differentiation among teachers. In addition, such an inconsistency among the studies suggests further investigating the gender effects on phubbing behaviors.

The results reveal that teachers' phubbing levels differ according to their marital status. Specifically, nomophobia and self-isolation scores of single teachers are higher than married ones. However, in the study conducted by Aydoğdu and Çevik (2020), both levels of phubbing and being phubbed were found to be independent on marital status. Based on the results for teachers' factor scores of GSP by marital status, it can be thought that single teachers' anxiety about being away from smartphones and isolating themselves from social environments are higher than those of married ones. One possible reason for this result may be that marriage requires individuals to spare time 
for their spouse and children and requires more intense social interaction than singles and thus the time and interest to be devoted to smartphones may decrease. This can also be said as an explanation of the negative relationship between age and self-isolation factor of phubbing. When an individual get older, his/her social environment or circle normally expands due to his/her marriage and professional responsibilities.

As with all research studies, this study has limitations as well. First of all, it was designed as a descriptive survey research and therefore no definitive conclusions can be made germane to cause and effect relationships among the variables. Secondly, convenience sampling was applied to recruit the participating teachers without considering their school levels and locations. Hence, the findings may not be representative to all teachers. Finally, the operationalization of variables, particularly those related to GSP and GSBP, were based on the self-report data.

Considering the limitations and results of the study, the following suggestion can be made for further research on the context of phubbing behaviors:

1. Studies can be conducted to examine other factors affecting teachers' level of phubbing and being phubbed.

2. Qualitative studies can be conducted to deeply describe the relatively new concept of phubbing and its relationships to demographics.

3. Scales measuring phubbing and being phubbed in younger age groups can be developed.

\section{Ethical Standards}

\section{Compliance with Ethical Standards}

All study procedures involving human participants followed institutional and/or national research committee ethical standards and the 1964 Helsinki declaration and its later amendments or comparable ethical standards. This study has also been approved by the authors' university Institutional Review Board (15.04.2021-106/31).

\section{Author Contributions}

The authors developed the concept for this manuscript, carried out the literature search, critically analyzed the data, wrote the manuscript, and proofread it.

\section{Declaration of Conflicting Interests}

The author(s) declared no potential conflicts of interest with respect to the research, authorship, and/or publication of this article.

\section{Funding}

The author(s) received no financial support for the research, authorship, and/or publication of this article.

\section{Data Availability}

The datasets generated during and/or analyzed during the current study are available from the corresponding author on reasonable request.

ORCID

Emre Suzer@https://orcid.org/0000-0002-5927-3869

Mustafa Koc@i@ttps://orcid.org/0000-0002-3276-7172

Received: October 10, 2021

Accepted: October 23, 2021

Published Online: October 28, 2021

\section{References}

Anshari, M., Alas, Y., Hardaker, G., Jaidin, J. H., Smith, M., \& Ahad, A. D. (2016). Smartphone habit and behavior in Brunei: Personalization, gender, and generation gap. Computers in Human Behavior, 64, 719-727. https://doi.org/10.1016/j.chb.2016.07.063

Aydoğdu, F., \& Çevik, Ö. (2020). Okul Psikolojik Danışmanlarının Sosyotelist Davranışlarının, Sosyotelizme Maruz Kalma ve Yalnızlık Düzeyleri Üzerindeki Etkisinin İncelenmesi. Humanistic Perspective, 2(3). https://doi.org/10.47793/hp.810850

Büyüköztürk, Ş. (2020). Sosyal bilimler için veri analizi el kitabı. Ankara: Pegem Akademi Yayıncılık. 
Chotpitayasunondh, V., \& Douglas, K. M. (2016). How "phubbing" becomes the norm: The antecedents and consequences of snubbing via smartphone. Computers in Human Behavior, 63, 9-18. https://doi.org/10.1016/j.chb.2016.05.018

Chotpitayasunondh, V., \& Douglas, K. M. (2018a). Computers in Human Behavior Measuring phone snubbing behavior: Development and validation of the Generic Scale of Phubbing (GSP) and the Generic Scale of Being Phubbed. Computers in Human Behavior, 88(March), 5-17. https://doi.org/10.1016/j.chb.2018.06.020 Chotpitayasunondh, V., \& Douglas, K. M. (2018b). The effects of "phubbing" on social interaction. Journal of Applied Social Psychology, 48(6), 304-316. https://doi.org/10.1111/jasp.12506

Creswell, J. W. (2012). Educational Research (4. bask1). https://doi.org/10.4324/9781315092171-19

Ergün, N., Göksu, İ., \& Sakız, H. (2020). Effects of Phubbing: Relationships With Psychodemographic Variables. Psychological Reports, 123(5), 1578-1613. https://doi.org/10.1177/0033294119889581

Erzen, E., Odaci, H., \& Yeniçeri, İ. (2021). Phubbing: Which Personality Traits Are Prone to Phubbing? Social Science Computer Review, 39(1), 56-69. https://doi.org/10.1177/0894439319847415

İliç, U., \& Tanyeri, T. (2021). Is phubbing a matter for educators: A case for pre-service and in-service teachers. Malaysian Online Journal of Educational Technology, 9(1), 70-79. https://doi.org/10.17220/mojet.2021.9.1.246

Karadağ, E., Tosuntaş, Ş. B., Erzen, E., Duru, P., Bostan, N., Mızrak Şahin, B., Çulha, İ., \& Babadağ, B. (2016). The Virtual World's Current Addiction: Phubbing. Addicta: The Turkish Journal on Addictions, 3(2). https://doi.org/10.15805/addicta.2016.3.0013

Karadağ, E., Tosuntaş, Ş. B., Erzen, E., Duru, P., Bostan, N., Şahin, B. M., Çulha, I., \& Babadağ, B. (2015). Determinants of phubbing, which is the sum of many virtual addictions: A structural equation model. Journal of Behavioral Addictions, 4(2), 60-74. https://doi.org/10.1556/2006.4.2015.005

Kemp, S. (2021). Digital 2021 - We Are Social. https://wearesocial.com/digital-2021

Krasnova, H., Abramova, O., Notter, I., \& Baumann, A. (2016). Why phubbing is toxic for your relationship: Understanding the role of smartphone jealousy among "Generation Y" users. 24th European Conference on Information Systems, ECIS 2016, April.

Nazir, T \& Pişkin, M. (2016). Phubbing: A Technological Invasion Which Connected the World But Disconnected Humans. The International Journal of Indian Psychology, 3(4), 175-182. https://doi.org/10.25215/0403

Nazir, T. (2020). Impact of classroom phubbing on teachers who face phubbing during lectures. Psychology Research on Education and Social Sciences, 1(June), 41-47.

Orhan Göksün, D. (2019). Sosyotelist Olma ve Sosyotelizme Maruz Kalma Ölçeklerinin Türkçeye Uyarlanması. Afyon Kocatepe Üniversitesi Sosyal Bilimler Dergisi, 21(3), 657-671. https://doi.org/10.32709/akusosbil.505642

Roberts, J. A., \& David, M. E. (2016). My life has become a major distraction from my cell phone: Partner phubbing and relationship satisfaction among romantic partners. Computers in Human Behavior, 54, 134-141. https://doi.org/10.1016/j.chb.2015.07.058

Roberts, J. A., \& David, M. E. (2017). Put down your phone and listen to me: How boss phubbing undermines the psychological conditions necessary for employee engagement. Computers in Human Behavior, 75, 206-217. https://doi.org/10.1016/j.chb.2017.05.021

Roberts, J. A., Yaya, L. H. P., \& Manolis, C. (2014). The invisible addiction: Cell-phone activities and addiction among male and female college students. Journal of Behavioral Addictions, 3(4), 254-265. https://doi.org/10.1556/JBA.3.2014.015

Şen, S., \& Yıldırım, İ. (2019). Eğitimde Araştırma Yöntemleri (1. baskı). Ankara: Nobel Yayıncılık.

Tabachnick, B. G., \& Linda S. Fidell. (2013). Using Multivariate Statistics. Içinde Contemporary Psychology: A Journal of Reviews (6th Editio, C. 28, Say1 8). Pearson.

Turkle, S. (2011). Alone together: Why we expect more from technology and less from each other. Içinde Basic Books, Inc.

Ugur, N. G., \& Koc, T. (2015). Time for Digital Detox: Misuse of Mobile Technology and Phubbing. Procedia Social and Behavioral Sciences, 195, 1022-1031. https://doi.org/10.1016/j.sbspro.2015.06.491

Yam, F. C., \& Kumcagiz, H. (2020). Adaptation of General Phubbing Scale to Turkish Culture and Investigation of Phubbing Levels of University Students in Terms of Various Variables. ADDICTA: The Turkish Journal on Addictions, 7(1), 48-60. https://doi.org/10.5152/addicta.2020.19061 